\title{
Releasing Housing Equity in Later Life: Markets, Consumers and the Role of the State
}

\author{
Lorna Fox O'Mahony and Louise Overton
}

\begin{abstract}
The role of equity release transactions in enabling older owners to draw down on their housing wealth to meet needs and wants in later life is a prominent policy trope in many asset-based welfare systems. Framed by the enactment of the Consumer Credit Legislation Amendment (Enhancement) Act 2012 (Cth) - in which the Federal Government established regulatory jurisdiction over reverse mortgage transactions - and drawing on empirical research into the uses and risks of housing equity withdrawal mechanisms in Australia, ${ }^{1}$ this article compares the recent Australian experience of equity release with the longer-established UK equity release market. Reaching across the demographic, socio-economic and policy contexts which are widely regarded as setting the scene for increasing use of housing wealth to fund financial needs after retirement, to the nature and development of equity release markets, this article draws on the UK experience to reflect on patterns of supply and demand, on the needs, circumstances and objectives of the equity release consumer population, and on the role of the state, through law and policy, in mediating the transactional interface between consumers and markets to support the matrix of consumer interests, industry growth and related government policy agendas implicated in the equity release market.
\end{abstract}

\section{INTRODUCTION}

A key aspect of the 'ageing society' under asset-based welfare concerns the ways in which ageing owners use - and are expected by governments to use - their housing equity to support various activities and needs in later life. The use of accumulated housing equity as an encashable financial resource is a central component of narratives advancing asset-based welfare policies in the United Kingdom, where - as in Australia, and in many other neoliberal homeownership societies ${ }^{2}$ - housing 'wealth' has come to be viewed as part of the solution to the demographic and fiscal pressures associated with an ageing population. ${ }^{3}$ Policy frames in which governments increasingly

1 Rachel Ong et al, Housing equity withdrawal: Uses, risks and barriers to alternative mechanisms in later life (AHURI Final Report No 217, October 2013).

2 See, eg, John Doling and Richard Ronald, 'Home-ownership and asset-based welfare' (2010) 25(2) Journal of Housing and Built Environment 165; Richard Groves, Alan Murie and Christopher Watson, Housing and the new welfare state: Examples from East Asia and Europe (Aldershot: Ashgate, 2007).

3 Peter Malpass, 'Housing and the New Welfare State: Wobbly Pillar or Cornerstone?' (2008) 23(1) Housing Studies 1. 
look to the 'decumulation' of housing equity as a resource to meet needs in later life raise important questions about the role of the State in supporting or enabling an effective market for housing equity transactions. ${ }^{4}$

It has been widely recognised, both in Australia and in the United Kingdom, that the financial and legal risks associated with equity release - and older consumers' perceptions of those risks - have been a significant barrier to the growth of the equity release market and, in turn, to the realisation of policy goals that rely on the 'decumulation' of housing equity. In a major new study for the Australian Housing and Urban Research Institute, Ong et al noted that, while the development of the equity release market offers older Australians a 'new, potentially promising, form of financial innovation that aims to mitigate some of the risks associated with debt-based forms of finance', consumer perceptions of risk - including negative product features, anxieties about appropriate information and advice, and the stigma associated with the equity release or 'reverse mortgage' industry - are a barrier to take-up. ${ }^{5}$ Taking as its starting point the proposition that the goals of government regulation generally, and the Consumer Credit Legislation Amendment (Enhancement) Act 2012 (Cth) specifically, include building consumer confidence in financial markets, this article explores the development of reverse mortgage regulation in Australia. The discussion is embedded in the context of the developing market, drawing comparisons from the United Kingdom's experience to reflect on the complex relationships between the industry's offer, the consumer population, and the (current and potential) role of the State through law, policy and regulation.

The role of financial services regulation in any given market is framed by the nature and extent of the risks that borrowers and lenders negotiate in financial transactions. These risks vary according to the nature of the transaction - with some types of financial transaction (including pay-day loans, debt consolidation, and reverse mortgage/equity release transactions) recognised as inherently 'high-risk'. The decision to bring any product under the jurisdiction of the Australian Securities and Investment Commission (ASIC) is underpinned by a concern that the general law of contract, consumer protection and other statutory regulation do not adequately address the particular risks that consumers negotiate in this type of transaction. The move to develop a bespoke regime for reverse mortgages in Australia echoes similar moves in the United Kingdom, a decade earlier; and, indeed, the Australian approach to regulation of reverse mortgages has followed a broadly comparable approach to that taken in the United Kingdom, now under the jurisdiction of the Financial Conduct Authority (FCA). In Australia, the case for specific regulatory intervention was rooted in an ASIC investigation, ${ }^{6}$ which highlighted

4 Lorna Fox O'Mahony, Home Equity and Ageing Owners: Between Risk and Regulation (Hart Publishing, 2012).

$5 \quad$ Ong et al, above $\mathrm{n} 1$.

6 ASIC, 'All We Have is This House': Consumer Experiences with Reverse Mortgages, Report 109 (November 2007). 
areas of market failure resulting from lenders providing misleading information, unregulated advisors providing misleading or inadequate information, and a lack of mandatory standards for the provision of legal or financial advice about reverse mortgages. ${ }^{7}$ This report also identified the lack of any standard method of presentation for reverse mortgages, as well as problematic practices relating to 'no negative equity guarantee', default and occupancy clauses; ${ }^{8}$ and the financial terms of the reverse mortgage (for example, interest rates, loan-to-value (LTV) ratio and so on). ${ }^{9}$ The Australian Government issued a Green Paper that included reverse mortgage regulation in $2008,{ }^{10}$ while - at the same time - calls for the industry to take its own steps to increase consumer confidence led to the development of a package of industry self-regulation under SEQUAL (the Senior Australians Equity Release Association of Lenders). ${ }^{11}$ More recently, the Australian Government enacted the Consumer Credit Legislation Amendment (Enhancement) Act 2012, which is framed under a commitment to 'limited' statutory intervention. ${ }^{12}$

These developments are particularly significant in a political context that is poised towards housing equity decumulation as a vehicle for self-provision in later life. The risk-sharing relationship between the market, the State and the consumer is central to successful outcomes on all sides of these transactions: to overcome barriers to market growth; to increase older owners' participation in housing-asset based welfare strategies for later life; and to build consumer confidence and support good consumer outcomes from reverse mortgage transactions. In both the United Kingdom and Australia, the current approach to regulation involves a combination of statutory regulation and industry-led regulation, against a backdrop of contract law and general consumer protection legislation. While the impacts of the 2012 Act remain to be seen, this article opens up a contextualised analysis of this significant departure in Australian law by comparing the more recent Australian experience with the longer-established United Kingdom market, to reflect on the changing relationships between consumers, markets and States as they are played out in this strategically significant sector of the financial services industry.

\section{Market Contexts}

While the availability of reverse mortgages in Australia is a relatively recent, largely twenty-first century phenomenon, the United Kingdom

7 Fiona Burns, 'The Evolving Statutory Regulation of Reverse Mortgages in Australia's “Risk Society" (2013) 39 Monash University Law Review 611, 623-625.

8 Ibid, 625-628.

9 Ibid, 628-631.

10 Treasury, 'Financial Services and Credit Reform: Improving, Simplifying and Standardising Financial Services and Credit Regulation' (Green Paper, June 2008).

11 See below, section IV.D.

12 Burns, above n 7. 
industry has a much longer history. The United Kingdom's first equity release plans targeted at older consumers were launched by Hodge Lifetime (then 'Home Reversions Ltd') in 1965; and 'mortgage and annuity' schemes, or 'Home Income Plans' became available from 1972. Several providers were active in the market throughout the 1960s, 1970s and 1980s. More recently, the policy context of housing-asset-based-welfare, against a backdrop of increasingly innovative and flexible products following financial deregulation from the 1980s, has highlighted a significant strategic role for equity release in meeting the financial needs of the United Kingdom's ageing population. ${ }^{13}$

In the United Kingdom context, the market for regulated equity release products has remained relatively small within the overall financial services industry, and is widely perceived as under-developed relative to projections for growth. ${ }^{14}$ Estimates of the total size of the market vary because of a lack of centralised publicly available data, but 2009 predictions from the Office for National Statistics suggested that equity release products are used by around 2 per cent of owner occupiers over the age of $65 ; ;^{15}$ and at just over half a percent ${ }^{16}$ of the total mortgage market in 2013 , it remains a specialised sector. The market peaked at the height of the property boom in 2007, but the global financial crisis (GFC) had a negative impact on supply and demand. More recently, there is evidence of recovery, as 2013 saw the highest level of growth in five years, ${ }^{17}$ with more than $£ 1$ billion worth of housing wealth released by older owners aged 55 and over. ${ }^{18}$

The strategic importance of the equity release market was underlined in a 2013 House of Lords' Select Committee report, Ready for Ageing, which noted the significance of 'an effective equity release market to unlock the housing assets held by older people'. ${ }^{19}$ The current under-use

13 Janneke Toussaint and Marja Elsinga, "Exploring "housing asset-based welfare": Can the UK be held up as an example for Europe?' (2009) 24(5) Housing Studies 669; John Doling and Richard Ronald, 'Property-based welfare and European homeowners: how would housing perform as a pension?' (2010) 25 Journal of Housing and the Built Environment 227.

14 Actuarial Profession, Equity Release Report Volume 1 (Actuarial Profession, 2005); see also Toussaint and Elsinga, above n 13, describing the relative lack of engagement of UK households in housing asset-based welfare.

15 Office for National Statistics, Wealth in Great Britain: main results from the wealth and assets survey 2006/2008 (2009) <http://www.ons.gov.uk/ons/rel/was/wealthin-great-britain/main-results-from-the-wealth-and-assets-survey-2006-2008/ index.html>.

16 Equity release advances were valued at £1074 million in 2013 (data provided by the Equity Release Council), against total gross mortgage lending of $£ 177$ billion for 2013 (Council for Mortgage Lenders).

17 The market by value grew by 36 per cent between 2011 and 2013: data provided by the Equity Release in personal communication.

18 Equity Release Council, Equity Release Market Report (2014)<http://www.equityreleasecouncil.com/document-library/equity-release-market-report-spring-2014/>.

19 HL Paper 140, London: TSO, 14 March 2013 [41]. 'Equity release could enable more people to use their assets to help pay for the cost of their social care (see 
of products has been linked to 'quite considerable' market failures, with 'knock-on effects for both the market in suitable housing for older people, and older people's ability to adapt their homes for older age'. ${ }^{20}$ Barriers to older owners' willingness to spend their housing wealth echo findings from Australian research, ${ }^{21}$ and include concerns about the complexity, riskiness and value for money of such schemes, ${ }^{22}$ with the perception that they are 'very risky' the strongest factor against consumer uptake of equity release. ${ }^{23}$ Recognising the 'urgent need for greater consumer confidence in the equity release industry', the Committee proposed that 'the Government should work with the financial services industry to encourage the growth of a safe and easy-to-understand equity release market'. ${ }^{24}$

The nature and extent of the United Kingdom's equity release market, and the differentiated needs, circumstances and objectives of the consumer population, provide a crucial starting point from which to consider the role of the State in mediating the transactional interface between consumers and markets, in mitigating the risks of housing equity withdrawal, and in aligning an appropriate degree of consumer protection with industry strategies for market growth in the shadow of policy agendas geared towards greater use of housing equity in later life. This section begins by comparing data on the United Kingdom market context with patterns of growth in the Australian equity release market, to map out the context in which the Consumer Credit Legislation Amendment (Enhancement) Act 2012 will operate and to highlight its potential role in building consumer confidence in this strategically important market.

\section{A Product Types}

Following a decline in the popularity of home reversion plans since the mid-2000s, ${ }^{25}$ the United Kingdom market is dominated by lifetime mortgages. Products typically operate a minimum age threshold: the consumer must usually be at least 55 years old to qualify for a lifetime mortgage and at least 60 years old for a home reversion plan. This reflects the main risk associated with equity release products for providers: that the provider will generally have to wait until the owner moves out of the property or dies before money owed (in the form of the capital asset of the house) is

Annex 11), to adapt their homes (see Annex 16), and to support their incomes'; ibid, [138].

20 Ibid, [140]. Research has indicated that barriers to older owners' willingness to spend their housing wealth include concerns about the complexity, riskiness and value for money of such schemes, with the perception that they are 'very risky' being the strongest factor against equity release: Karen Rowlingson, 'Attitudes to housing assets and inheritance' (2005) 10 CML Housing Finance, Chart 3.

21 Ong et al, above $\mathrm{n} 1$.

22 Rowlingson, above n 20, 1.

23 Ibid, Chart 3.

24 Ibid, [143].

25 FSA, Regulation of Home Reversion and Home Purchase Plans, Volume 1 Consultation Proposals (CP 06/8) (FSA, 2006), Chart to [2.7]. 
recovered. Table 1 sets out the key features of the main equity release products in the current United Kingdom market.

Table 1: Equity release products in the United Kingdom

\begin{tabular}{|l|l|}
\hline Product type & How does it work? \\
\hline $\begin{array}{l}\text { Lifetime mortgage/ } \\
\text { 'reverse mortgage' }\end{array}$ & $\begin{array}{l}\text { Includes a range of products in which the debt, interest payments } \\
\text { and charges are accumulated over the lifetime of the product, and } \\
\text { scheduled for repayment not by instalments but using the proceeds } \\
\text { from the sale of the property. }\end{array}$ \\
\hline $\begin{array}{l}\text { Lump sum lifetime } \\
\text { mortgage }\end{array}$ & $\begin{array}{l}\text { Interest accumulates every month, but 'repayments' are 'rolled up' } \\
\text { or added to the mortgage capital, with the whole debt paid off when } \\
\text { the borrower dies, goes into long-term care or for any other reason } \\
\text { vacates the property. }\end{array}$ \\
\hline $\begin{array}{l}\text { Drawdown lifetime } \\
\text { mortgage }\end{array}$ & $\begin{array}{l}\text { Similar to lump sum, except that a maximum borrowing amount is } \\
\text { agreed between the borrower and the lender, based on the value } \\
\text { of the property being used as security. Funds can be drawn as and } \\
\text { when needed, with undrawn funds not being subject to interest. }\end{array}$ \\
\hline Home reversion plan & $\begin{array}{l}\text { These plans involve the sale of the property (full reversion), or } \\
\text { a share in the property (partial reversion) in exchange for either } \\
\text { a lump sum payment, an income for life, or, in some cases, a } \\
\text { combination of lump sum and income; with an agreement allowing } \\
\text { the vendor to remain in occupation subject to certain conditions. }\end{array}$ \\
\hline
\end{tabular}

In Australia, the lifetime or 'reverse' mortgage is also the primary vehicle through which consumers, primarily people aged over 60, can borrow against the equity in their homes. There is only one home reversion scheme provider ('Homesafe Solutions') currently operating in Australia, and the product is only available to owners in specified areas of Sydney or Melbourne.

The structure and operation of lifetime mortgage products was one of three key areas identified by the Australian Securities and Investments Commission in its 2007 report on the experiences of reverse mortgage consumers. Particularly, the Commission noted that lenders' procedures on default should be appropriate to the age and vulnerabilities of this group of borrowers; that all lenders should be encouraged to include a no negative equity guarantee; and that lenders should consider structuring their reverse mortgages to facilitate disciplined money management and planning. ${ }^{26}$ Examples of this included not granting more credit than the borrower applies for; where loans are granted primarily for living expenses, offering the option of regular fortnightly or monthly payments; including a projection in the monthly statement to indicate the rate of depletion; responsible advertising, to avoid encouraging short-term spending and focusing on essential needs; providing access to budgeting tools and information; and allowing for a percentage of equity to be protected, for example, for inheritance. The extent to which the State has been prepared to intervene in product design, in the United Kingdom and in Australia, is discussed below in Part C. 


\section{B Supply}

The providers of lifetime mortgages and home reversions in the United Kingdom are typically insurers or specialist retirement financial services companies. Before the global financial crisis, a number of building societies offered equity release plans but this is no longer the case. Since 2008, some 'prime' lenders have withdrawn from the equity release market: in October 2009, Northern Rock withdrew its 'Lifetime' products, and by 2010 Prudential, Newcastle Building Society and Coventry Building Society had closed their doors to new equity release/lifetime mortgage business. Following the withdrawal of Northern Rock from the market in October 2009, there were no high street banks in the United Kingdom equity release market, although 2015 saw major financial services provider Legal \& General enter the market. The contraction of the pool of providers, and particularly the loss to the market of some high-profile 'mainstream' lenders, had left borrowers with fewer choices, so Legal \& General's acquisition of Newlife Home Finance, a lifetime mortgage provider, was a significant turning point.

The majority of equity release products sold in Britain (over 90 per cent by volume) are provided by members of industry body, the Equity Release Council (formerly 'Safe Home Income Plans' (SHIP)), which was launched in 1991 and which covers lifetime mortgages and home reversions. The Equity Release Council performs a similar function to SEQUAL, the Senior Australians Equity Release Association: all participating companies pledge to observe a Code of Practice, which binds the companies to provide a fair, easy-to-understand and full presentation of their plans, along with a number of protections and safeguards. By late 2010, there were 13 SHIP members in the equity release market, including both large sector-wide financial services providers (for example, Aviva Equity Release UK Ltd) and specialised providers (including Bridgewater which specialises in home reversion plans, and Hodge Lifetime which has offered equity release plans since 1965, making them the longest established provider in the United Kingdom). This number had dropped to 11 by 2014, echoing the Australian experience of market contraction during the global financial crisis, when a fall in the availability, and rising costs of wholesale funding adversely affected some reverse mortgage providers, particularly non-bank lenders. ${ }^{27}$ In Australia, the market contracted from 15 lenders in the lead up to the Global Financial Crisis to only five by $2013 .^{28}$

In the United Kingdom context, the absence of high street financial institutions from the market has been considered one of the factors

27 Catherine Bridge et al, Reverse Mortgages and older people: growth factors and implications for retirement decisions (AHURI Final Report No 146 Melbourne: Australian Housing and Urban Research Institute, 2010).

28 Deloitte/SEQUAL, 'Australia's Equity Release Market - an opportunity being missed' (Media Release, 2013). 
contributing to limited growth. ${ }^{29}$ SHIP suggested that the withdrawal of providers led to a fall in the number of lump sum lifetime mortgages in $2009,{ }^{30}$ at the same time as home reversions became more popular in light of the consumer advantage in selling a fixed portion of equity in a time of house price uncertainty. ${ }^{31}$ The geographically limited availability of home reversions to specified postcodes in Sydney and Melbourne mean that there is less scope for consumers to exercise this type of choice within the equity release market.

Table 2: Distribution of United Kingdom transactions across available product types

\begin{tabular}{|l|c|c|c|c|c|}
\hline Products \% & $\mathbf{2 0 0 9}$ & $\mathbf{2 0 1 0}$ & $\mathbf{2 0 1 1}$ & $\mathbf{2 0 1 2}$ & $\mathbf{2 0 1 3}$ \\
\hline Lump sum lifetime mortgages & 46 & 36 & 30 & 29 & 34 \\
\hline Draw down lifetime mortgages & 55 & 62 & 69 & 71 & 66 \\
\hline Home Reversion plans & 2 & 1 & 1 & $<1$ & $<1$ \\
\hline
\end{tabular}

Source: Equity Release Market Report, Spring 2014, The Equity Release Council

By the end of 2009 and into 2010, drawdown mortgages - which offer a more flexible way to release equity - were the most popular product in the United Kingdom, accounting for 55 per cent of the equity release market. ${ }^{32}$ These products have continued to grow in popularity, accounting for at least two in three products sold each year since 2011.

\section{Demand}

Before the downturn, the United Kingdom equity release market had grown steadily over a period of 15 years. As the industry moved to selfregulate with the formation of SHIP in 1991, the market remained very small: at the end of 1992,570 plans had been sold worth $£ 28.9$ million. ${ }^{33}$ By 2001 the market was worth $£ 572.2$ million, and a further period of growth continued until the 2007 downturn. Figure 1 (opposite) illustrates the pace of growth in the equity release market by value to around $£ 1.2$ billion by 2007; Figure 2 (opposite) illustrates a similar pattern of growth by volume (number of plans).

As the financial downturn contracted supply, the industry responded, in part, by offering greater product flexibility. The Equity Release Council (previously SHIP) have regarded product innovation as central

29 SHIP, Facing the Future: Redefining equity release to meet today's social and economic challenges (SHIP, 2009).

$30<$ http://www.mortgageintroducer.com/ccstory/236514/250/Equity_release_ market_stabilises_in_2009.htm>.

$31<$ http://www.mortgageintroducer.com/ccstory/236514/250/Equity_release_ market_stabilises_in_2009.htm>.

32 See SHIP statistics, SHIP, Ship 20th Anniversary Report December 1991 to December 2011 (24 May 2012) <http://www.equityreleasecouncil.com/ document-library/ship-20th-anniversary-report/>.

33 SHIP, 20th Anniversary Report (May 2012) Equity Release Council [4] <http://www. equityreleasecouncil.com/document-library/ship-20th-anniversary-report/>. 
Figure 1: Value of equity release plans (1992-2010)

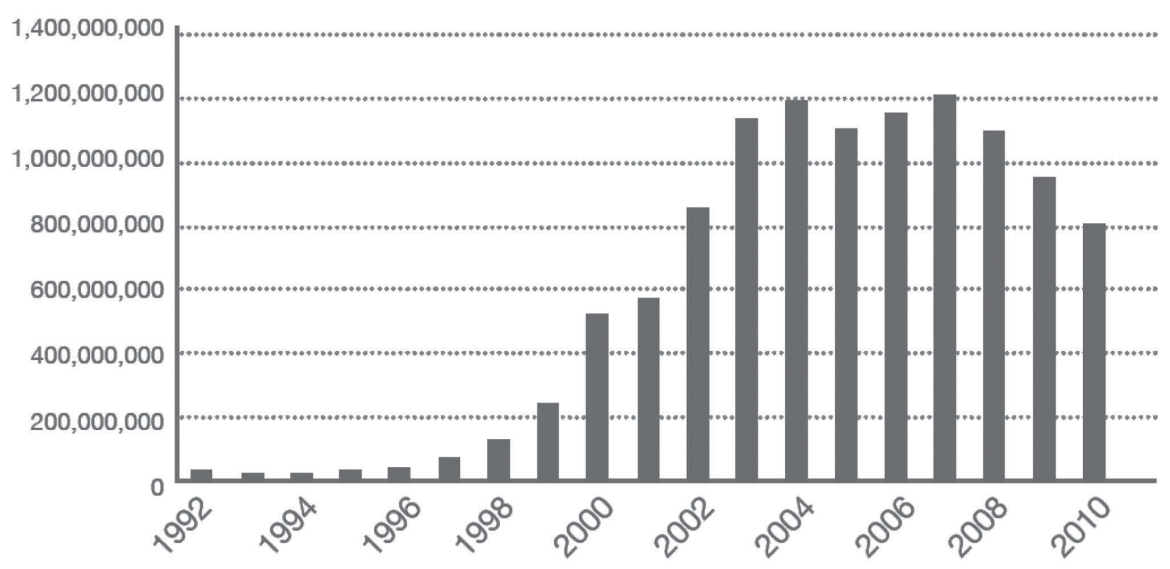

Figure 2: Volume of plans (1992-2010)

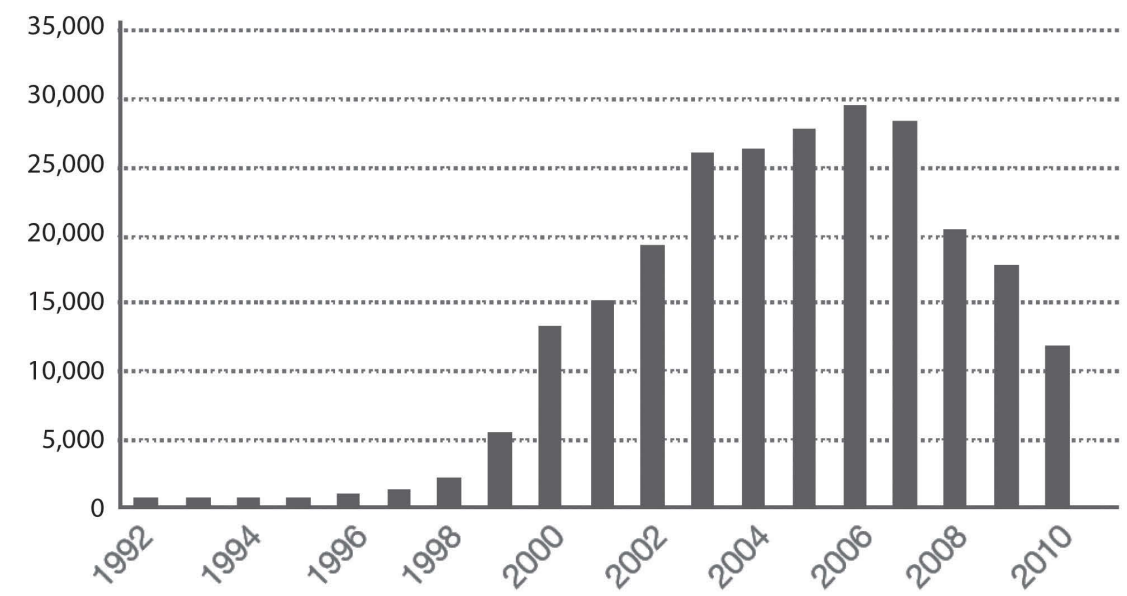

Source: SHIP, 20th Anniversary Report (May 2012) Equity Release Council [4] <http://www. equityreleasecouncil.com/document-library/ship-20th-anniversary-report/>.

to attracting more consumers to equity release and their members are keen to develop new products that meet a range of consumer needs, ${ }^{34}$ with new product features including:

- Inheritance guarantees: where consumers are able to protect a proportion of their property value from the outset.

- Impaired life schemes: (otherwise known as enhanced lifetime mortgages) take into account the health and lifestyle of the consumer, working on a similar principle to enhanced-rate annuities.

34 SHIP, The Equity Release Market (2011) <http://www.ship-ltd.org/ equityreleasemarket.aspx>. 
- Interest payment options: one provider who re-entered the market in 2011 now offers lifetime mortgages where consumers are able to pay off some of the interest during the life of the loan. This reduces the overall cost and increases the amount of equity remaining at the end of the loan term for potential bequest motives.

- Wider provision of drawdown: drawdown lifetime mortgages allow the borrower to obtain an agreed, maximum amount of money as and when required. It can reduce the effect of compound interest by allowing customers to take out smaller amounts of money at different periods rather than accessing a single, larger lump sum.

The newer, Australian equity release market experienced a similar period of pronounced growth in 2006 and 2007 (see Table 3, below), although it is noteworthy that despite the reduction in the number of SEQUAL members, and unlike the United Kingdom market which saw a substantial decline during this time, the Australian market continued to grow, albeit at a steady rate, in 2009 and 2010. By the end of 2013, the total value of the Australian equity release market stood at $\$ 3.6$ billion. ${ }^{35}$

Table 3: Number and value of outstanding Australian SEQUAL-compliant reverse mortgages

\begin{tabular}{|l|l|l|l|l|l|l|l|l|l|}
\hline & $\mathbf{2 0 0 5}$ & $\mathbf{2 0 0 6}$ & $\mathbf{2 0 0 7}$ & $\mathbf{2 0 0 8}$ & $\mathbf{2 0 0 9}$ & $\mathbf{2 0 1 0}$ & $\mathbf{2 0 1 1}$ & $\mathbf{2 0 1 2}$ & $\mathbf{2 0 1 3}$ \\
\hline Market size & $\$ 0.9 \mathrm{~b}$ & $\$ 1.5 \mathrm{~b}$ & $\$ 2.0 \mathrm{~b}$ & $\$ 2.5 \mathrm{~b}$ & $\mathbf{\$ 2 . 7 b}$ & $\$ 3.0 \mathrm{~b}$ & $\$ 3.3 \mathrm{~b}$ & $\$ 3.5 \mathrm{~b}$ & $\$ 3.6 \mathrm{~b}$ \\
\hline $\begin{array}{l}\text { Number of } \\
\text { loans }\end{array}$ & 16,584 & 27,898 & 33,741 & 37,530 & 38,788 & 41,640 & 42,410 & 42,455 & 41,435 \\
\hline
\end{tabular}

Source: Deloitte (December 2013) Reverse Mortgage Survey

As Ageing Australia increasing looks for solutions to the wealth and pension shortfall, equity release transactions are potentially significant in enabling older owners to meet financial needs in later life. Yet, market penetration of eligible households remains very low, estimated at about 3 per cent. ${ }^{36}$ The ageing population, high rates of home ownership amongst senior Australians (85 per cent of retirees aged 75 and older own their own home), and the declining ratio between working age population and retirees are shining a spotlight on the potential for older Australians to unlock housing wealth to fund their needs and wants in later life. The role of the State in creating the conditions in which this potential can be realised may have a range of foci, including the regulation of providers, products and transactions. In determining the appropriate role of the State, the market and policy contexts are significant; equally so, from a consumer protection and consumer confidence perspective, it is important

35 Deloitte Touche Tohmatsu and SEQUAL, Reverse Mortgage Survey, December 2013 (2013).

36 Christine Brownfield, 'The Fourth Pillar - The Role of Home Equity Release in Retirement Funding' (Paper presented to the Actuaries Institute Financial Services Forum, 5-6 May 2014) $8<$ http://actuaries.asn.au/Library/Events/ FSF/2014/BrownfieldFourthPillarPaper140505.pdf>. 
to understand the needs, objectives and characteristics of (potential) consumers, and how these shape the development of an appropriate and effective regulatory regime.

\section{The Consumer Context}

In a recent study for the Australian Housing and Urban Research Institute, Ong et al revealed that the purpose of housing equity withdrawal for many elderly Australians is to maintain - rather than increase - their spending in later life, most often because they do not hold adequate alternative financial resources to meet their needs. ${ }^{37}$ Ong et al highlighted the prevalence of socio-economic vulnerability within the older owner population, noting that "poor supports for decision-making about HEW [housingequity withdrawal] ... potentially ... expose many older Australians to financial vulnerability in retirement'. ${ }^{38}$ This is echoed, increasingly, in the United Kingdom, where socio-economic differentiation within the older owner population is a prominent feature of the consumer context, and an important factor in evaluating the appropriateness of approaches to regulation. ${ }^{39}$

Table 4: Why are equity release products used?

\begin{tabular}{|l|c|}
\hline Use(s) of money (2009) & \% \\
\hline House maintenance/repairs & 46 \\
\hline Holidays & 36 \\
\hline Debt clearance & 35 \\
\hline House/garden improvements & 33 \\
\hline Help out or treat family/friends & 26 \\
\hline Investment and saving & 24 \\
\hline Everyday living expenses/regular bills & 19 \\
\hline Leisure activities & 17 \\
\hline Other & 12 \\
\hline Reduce inheritance tax liability & 9 \\
\hline Pay for health/care needs & 8 \\
\hline Early retirement & 1 \\
\hline
\end{tabular}

Source: Overton, 2010. Participants were permitted to provide multiple answers therefore the total exceeds 100 per cent.

While an earlier United Kingdom survey of equity release consumers had revealed that the products were largely used for everyday living expenses

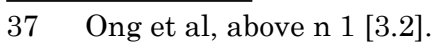

38 Ibid, 6.

39 Lorna Fox O’Mahony and Louise Overton, 'Financial Advice, Differentiated Consumers and the Regulation of Equity Release Transactions' (2014) 41(3) Journal of Law and Society 446. 
among middle-income homeowners, ${ }^{40}$ Overton's 2009 survey indicated that equity release is used to support retirement in a wider range of ways, as illustrated in Table 4 (above).

This study also found a correlation between consumer's circumstances and their reasons for using the products (see Table 5 below). Using cluster analysis, three groups of consumers were identified.

Table 5: Socio-economic characteristics of participants in Clusters 1, 2 and 3 (column percentages)

\begin{tabular}{|c|c|c|c|}
\hline & $\begin{array}{c}1 \\
\text { Passing it on } \\
n=99\end{array}$ & $\begin{array}{c}2 \\
\text { Enhancing later life } \\
n=190\end{array}$ & $\begin{array}{c}3 \\
\text { Getting by } \\
n=123\end{array}$ \\
\hline \multicolumn{4}{|l|}{ Income } \\
\hline Under $£ 10,000$ & 13 & 23 & 29 \\
\hline$£ 10,000-£ 14,999$ & 23 & 37 & 40 \\
\hline$£ 15,000-£ 19,999$ & 31 & 20 & 13 \\
\hline$£ 20,000$ or more & 33 & 20 & 18 \\
\hline \multicolumn{4}{|l|}{ Income source } \\
\hline Private pension & 93 & 87 & 82 \\
\hline State pension (ns) & 100 & 100 & 98 \\
\hline Pension credit & 10 & 10 & 23 \\
\hline Other SS benefits (ns) & 12 & 14 & 18 \\
\hline Savings and investments & 52 & 44 & 14 \\
\hline \multicolumn{4}{|l|}{ House value } \\
\hline Under $£ 100,000$ & 2 & 6 & 11 \\
\hline$£ 100,000-£ 149,999$ & 16 & 17 & 22 \\
\hline$£ 150,000-£ 199,999$ & 21 & 33 & 33 \\
\hline$£ 200,000-£ 249,999$ & 17 & 21 & 14 \\
\hline$£ 250,000-£ 299,999$ & 20 & 11 & 5 \\
\hline$£ 300,000$ or more & 24 & 12 & 15 \\
\hline \multicolumn{4}{|l|}{ Age (at plan) (ns) } \\
\hline Under 70 & 33 & 42 & 45 \\
\hline $70-74$ & 32 & 29 & 24 \\
\hline $75-79$ & 14 & 19 & 14 \\
\hline $80+$ & 21 & 10 & 17 \\
\hline \multicolumn{4}{|l|}{$\begin{array}{l}\text { Entered into plan with: } \\
\text { (ns) }\end{array}$} \\
\hline Husband/Wife/Partner & 60 & 60 & 55 \\
\hline No one else & 40 & 40 & 45 \\
\hline
\end{tabular}

$40 \quad$ Judith Davey, Equity Release: An option for older home-owners (University of York Centre for Housing Policy, 1996). 


\begin{tabular}{|l|c|c|c|}
\hline & $\begin{array}{c}\mathbf{1} \\
\text { Passing it on } \\
\mathbf{n = 9 9}\end{array}$ & $\begin{array}{c}\mathbf{2} \\
\text { Enhancing later life } \\
\mathbf{n = 1 9 0}\end{array}$ & $\begin{array}{c}\mathbf{3} \\
\text { Getting by } \\
\mathbf{n = 1 2 3}\end{array}$ \\
\hline Marital status & & & \\
\hline Married/cohabiting & 52 & 60 & 53 \\
\hline Separated/divorced & 15 & $\mathbf{2 0}$ & 16 \\
\hline Widowed & 28 & 12 & 23 \\
\hline Single & 5 & & 8 \\
\hline Children & & 70 & 77 \\
\hline Yes & 80 & 30 & 23 \\
\hline No & 20 & & \\
\hline
\end{tabular}

\section{Cluster 1: Passing it on}

The majority of consumers in this cluster (97 per cent) were already 'doing alright' or 'living comfortably' before entering into a plan, and they were financially better off than those in Clusters 2 and 3. In particular, they were more likely to have higher incomes, more valuable homes and savings and investments. Equity release was used strategically, either to transfer wealth to children or to make large, one-off purchases.

\section{Cluster 1 case illustration: $\mathrm{Mr}$ E}

$\mathrm{Mr} \mathrm{E}$ and his wife were in their early $70 \mathrm{~s}$; they were financially secure with good occupational pensions and a house worth $£ 550,000$, for which they originally paid $£ 5150$. They took out a Home Reversion plan to support their children. While the children were not in urgent need of financial support, $\mathrm{Mr} \mathrm{E}$ and his wife decided it would be more beneficial for them to have some of the value of their home now, rather than waiting until they died. Mr E also said that he benefited from doing this because he had the pleasure of seeing his children receive the money. Having enjoyed a significant increase in the value of their home, Mr E referred to this as 'money we haven't earned', which played a key role in their decision-making; it also helped them to decide on a Home Reversion plan, rather than a Lifetime Mortgage. Mr E had thought about the decision for some time before acting on it, and chose to use his own solicitor with whom he felt he had a good relationship, rather than a specialist solicitor recommended by the provider.

\section{Cluster 2: Enhancing later life}

These consumers were not 'finding it very difficult' to manage before taking out an equity release plan but neither were they 'living comfortably'. Equity release enabled them to maintain or enhance their lifestyles by allowing a wide range of housing and non-housing consumption. The money was commonly used for repairs, improvements, replacing household appliances and other essential items, but also for lifestyle purposes. 


\section{Cluster 2 case illustration: $M r M$}

Mr M was 79 and had never married. He was made redundant at age 57 during a period of high unemployment and was unable to get another job. By this point, he had paid off his mortgage and assumed that his redundancy package and pensions would be sufficient to 'see him out'. A few years down the line, however, he found that his pension income was not keeping up with the cost of living and he was finding it hard to meet all of his housing costs. These included an annual maintenance bill of $£ 1000$ since he lived in a communal block of flats. A survey of the roof of the flats also revealed that major repairs were necessary at a cost of $£ 25,000$ per owner. Mr M had very little savings and a fairly modest annual income of $£ 11,000$ after tax, so could not afford to pay for the repairs. His flat, however, was worth between $£ 350,000$ and $£ 400,000$, so he was asset-rich and relatively income-poor. Before equity release, $\mathrm{Mr} \mathrm{M}$ said he had to be very careful with his money and hadn't been on holiday in 18 years, but the roof repair bill prompted his decision to take out a lifetime mortgage. Before investigating equity release, he attempted to get a bank loan but was refused on the basis of his age, so he looked at other options and, with the help of a friend (who was a lawyer), did a lot of research before approaching a specialist equity release adviser to help him with making the final decision. He borrowed $£ 70,000$ of which $£ 30,000$ was spent on roof repairs. Part of the remaining sum was saved, while the rest was spent on other house repairs and improvements, holidays and enjoying a more comfortable retirement. Mr M says equity release gave him a new lease of life.

\section{Cluster 3: Getting by}

The majority of consumers in this cluster were 'finding it difficult' to manage or were only 'just about getting by' before they took out their equity release plans. Many were not only finding housing costs difficult to meet but they also tended to be in debt and had used equity release to help clear some of the money they owed.

\section{Cluster 3 case illustration: $M s$ C}

Ms C was 83 years old at the time of interview and had taken out a home reversion plan over ten years ago to help her manage with regular bills and living expenses. She had retired with a small occupational pension and no savings. This meant she was struggling to manage housing and living costs. She traded down to a smaller house in a cheaper area, but still found things difficult. Ms C took out an income-based plan, and some years later took out a small lump sum to help pay off debts accrued to the credit card which she had relied on to pay for one-off purchases such as a new boiler and fridge-freezer. Ms C says she now owns about 5 per cent of her house. She lives in an old Victorian terraced house, valued at 
around $£ 115,000$, with very steep stairs and says she feels trapped in a house that is unsuitable for her.

The needs, objectives and characteristics of the equity release consumer have significant bearing on reverse mortgage regulation debates. In Australia, concerns about the nature and rate of equity depletion, ${ }^{41}$ and the absence, in some products, of features such as minimum age or mandatory loan-to-value ratio on equity depletion ${ }^{42}$ highlight a significant relationship between product development on the one hand (whether this is achieved through market evolution, industry self-regulation or government regulation of terms and conditions), and the nature, extent, and purposes for which Australian consumers may wish to use reverse mortgages. Ong et al have emphasised the bifurcation within the Australian market, between consumers in strong financial and employment situations, on the one hand, and financially vulnerable consumers on the other, noting that '[f]or some, adverse life events may force them to make financial decisions related to the sale of their home due to time pressures, preventing information gathering and considered planning, and hence elevating the risks of making unsound financial judgments during crisis events'. ${ }^{43}$ Australian homeowners making housing equity withdrawals are more likely to suffer from material deprivation, and to have housing-oriented wealth profiles, than those who do not, with income-poor housing-asset-rich groups featured prominently among those cashing in housing equity. ${ }^{44}$ Within the wider category, in situ borrowing remains more prevalent among owners below pension age, with those above pension age more likely to downsize or sell up, and, once they have done so, tending to have very little income or assets to fall back on when hit by adverse life events. Furthermore, and noting that the Ong et al report does not specify characteristics within the equity release sub-population, if the Australian market echoes the United Kingdom experience it is likely that while those who sell up are the least well off amongst the three groups (selling up, downsizing, in situ borrowing), reverse mortgage consumers (as a sub-population of all equity withdrawers) are likely to be socio-economically diverse ${ }^{45}$ with significant implications for the consumer protection needs of this population. ${ }^{46}$

$41 \quad$ See ASIC, above n 6, 27-30.

42 See Green Paper, above n 10, 39-40.

43 Ibid, 2.

44 Ong et al, above n 1, [7.1.1].

45 To date, the Australian research does not specifically reveal the socio-economic composition of the in situ borrower population, or the distribution between those who take out targeted later-life home equity decumulation products, and those who make mortgage equity withdrawals using second (forward) mortgages, further advances, or any other form of home equity finance; Ong et al, above $n 1$. While Bridge et al, above n 27, focused solely on reverse mortgage borrowers, they rely on providers and brokers to tell them about consumers rather than surveying or interviewing consumers; and the information does not include socio-economic profiles.

46 See Fox O'Mahony and Overton, above n 39. 
In a neo-liberal landscape that is poised for greater 'self-reliance' through strategies of (particularly housing) asset accumulation and decumulation across the life-course, and tensioned against the argument that older owners should have the option of 'ageing in place', ${ }^{47}$ the development of a safe, reliable, good value equity release market has potentially significant implications for patterns of participation with asset-based welfare in later life, with knock-on effects for ageing population policies, for industry growth, and for the wellbeing of older owners. If - as has been suggested - this sector is to play an increasing role in supporting the needs of Australia's ageing population, the composition and characteristics of the consumer population, as well as the market offer, are crucial to determining an appropriate role for the State, through law and policy, to support and enable positive outcomes for industry growth and for consumer well-being.

\section{The Role of the State in Regulating Equity Decumulation Transactions}

An industry agenda for market growth, government policy agendas geared towards use of housing equity to fund later life, and the wide-ranging circumstances of a socio-economically heterogeneous consumer base, provide important context for critical analyses of the role of the State, through law and policy, in mediating the transactional interface between equity release consumers and markets. Equity release transactions are regulated through a variety of distinct but overlapping measures. First, they are subject to the standard law of contracts and to general consumer protection laws. Secondly, targeted products are specifically regulated under financial services regimes (in the United Kingdom, under the jurisdiction of the Financial Conduct Authority; in Australia, under the Consumer Credit Legislation Amendment (Enhancement) Act 2012), in recognition of the higher risk they pose to consumers. Finally, a significant majority of providers subscribe to industry self-regulation under the United Kingdom's Equity Release Council (ERC) and Australian's SEQUAL. ${ }^{48}$ The extent to which the State, through law, has responded to the particular policy, consumer protection and market growth agendas invoked by housing equity draw down using reverse mortgage transactions in any given jurisdiction is a product of these multi-layered approaches.

\section{A Contract and Consumer Protection Law}

The general backcloth to specific regulation of equity release transactions in each jurisdiction is coloured by contract law's 'vitiating factors' and

47 Lorna Fox O'Mahony and Louise Overton, 'Asset-Based Welfare, Equity Release and the Meanings of Owned Homes' (2015) 30 Housing Studies 392 for analysis of a recent consumer study exploring the tensions surrounding the use of the owned home as an asset-base for older owners. 
consumer credit regulations. The general law of contract polices fundamental matters concerning the structure and execution of the contract: for example, allowing a party to withdraw from a contract executed under duress or undue influence (for example, pressure exerted by a person), or following a material misrepresentation by the other party. There are also a number of generic 'fairness' provisions within the United Kingdom's general consumer law, which - although not specific to equity release transactions - are potentially applicable. Provisions regulating contractual terms have included the Unfair Terms in Consumer Contracts Regulations 1999 (UK), Consumer Credit Act 1974 (UK) (as amended by the Consumer Credit Act 2006 (UK)), and the Consumer Protection from Unfair Trading Regulations 2008 (UK). The aims of these provisions include policing 'unfair terms' or 'unfair relationships' in consumer contracts, as well as setting minimum standards of commercial practice in areas such as control over credit advertising and unfair marketing or sales practices, and the form and content of the information given to consumers, before, in, and after contracts are agreed. ${ }^{49}$ These provisions set an outer limit on the provider's freedom in the area of product design, although the English experience has been that the threshold for establishing that a term is 'unfair' is high, with English courts, when asked to determine the fairness of terms, tending to focus more on protecting the freedom of commercial lenders to conduct their business according to their own best interests, than on the particular vulnerabilities of a consumer, or the context of the contract..$^{50}$

England's longer experience of reverse mortgage markets and regulation has also revealed the limitations of remedial approaches in achieving adequate consumer protection for older owners in housing equity transactions. While the 'fairness' provisions have a role in resolving individual complaints, as well as setting standards of conduct for lenders, they are 'remedial' inasmuch as they operate after the event: relief is triggered in litigation, when the vulnerable party has already suffered harm; and they depend on the injured party making a complaint. This is particularly salient for older people, in light of the particularly detrimental impact of financial harms for consumers who are no longer income generating and so are likely to have limited opportunities to recover. ${ }^{51}$ There is also evidence to indicate that older people are less likely than the general consumer population to bring actions for redress. ${ }^{52}$ Qualitative research

49 Fox O'Mahony, above $\mathrm{n} 4$, especially ch 8.

50 See, eg, UK Housing Alliance (North West) Ltd v Francis [2010] EWCA Civ 117.

51 See, eg, Gillian Crosby et al, Financial Abuse of Older People: A review of the literature carried out by the Centre for Policy on Aging on Behalf of Help the Aged (Help the Aged, 2008) 23.

52 While there are many cases on issues relevant to older consumers, there are relatively few reported cases on housing equity transactions brought by older people. Research has also shown that the practical barriers to accessing 'safetynet' protections may be much higher for low-income consumers; see Therese Wilson, Nicola Howell and Genevieve Sheehan, 'Protecting the Most Vulnerable in Consumer Credit Transactions' (2009) 32 Journal of Consumer Policy 117, 126. 
with older consumers has indicated that they 'felt they had few options for redress when faced by problems with services; that older people lack the confidence, skills and stamina necessary to pursue complaints, so feel simply unable to effect change'; ${ }^{53}$ and that older consumers are 'particularly averse' to using law to seek solutions because it resonates with a 'compensation culture'; because they did not believe that it should be necessary to use courts to resolve problems; they lacked faith that the law to produce a positive outcome; and they lacked confidence that they had the knowledge or skills to negotiate the legal process to seek redress. ${ }^{54}$

The administrative enforcement of consumer protection through financial services regulation offers greater potential scope to address issues at an industry level. Furthermore, the United Kingdom experience has been that the FCA (previously the FSA) and FOS (Financial Ombudsman Service) have typically been more ready than the courts ${ }^{55}$ to recognise that the context or circumstances of the transaction can make older people particularly vulnerable in financial transactions, leading firms to undertake to remove or adapt unfair terms, and to incur liabilities in damages. The United Kingdom's generic consumer protection regime includes the FCA's Principles of Business, which focuses on how terms are applied in practice, ${ }^{56}$ and the rules set out in its Codes of Practice (for example, the Conduct of Business Sourcebook (COBS) or the Mortgages and Home Finance: Conduct of Business Sourcebook

53 Frances Butler, Rights for Real: Older People, Human Rights and the CEHR (Age Concern, 2006), 9.

54 Ibid.

55 Paragon Finance $v$ Pender [2005] EWCA Civ 760; see also Paragon Finance $v$ Nash [2001] EWCA Civ 1466, [47], where Dyson LJ stated that '[t]he claimant is not a charitable institution. Its aim is to make a profit by lending money'.

56 The FSA have 11 Principles of Business: (1) Integrity - A firm must conduct its business with integrity; (2) Skill, care and diligence - A firm must conduct its business with due skill, care and diligence; (3) Management and control - A firm must take reasonable care to organise and control its affairs responsibly and effectively, with adequate risk management systems; (4) Financial prudence - A firm must maintain adequate financial resources; (5) Market conduct - A firm must observe proper standards of market conduct; (6) Customers' interests - A firm must pay due regard to the interests of its customers and treat them fairly; (7) Communications with clients - A firm must pay due regard to the information needs of its clients and communicate information to them in a way which is clear, fair and not misleading; (8) Conflicts of interest - A firm must manage conflicts of interest fairly, both between itself and its customers and between a customer and another client; (9) Customers: relationships of trust - A firm must take reasonable care to ensure the suitability of its advice and discretionary decisions for any customer who is entitled to rely upon its judgement; (10) Clients' assets - A firm must arrange adequate protection for clients' assets when it is responsible for them; (11) Relations with regulators - A firm must deal with its regulators in an open and co-operative way and must disclose to the FSA anything relating to the firm of which the FSA would reasonably expect notice; see Financial Conduct Authority, FSA Handbook (19 June 2014) <http://fsahandbook.info/FSA/html/ handbook/PRIN>. 
(MCOB)).$^{57}$ All firms are also expected to be able to demonstrate that they are 'Treating Customers Fairly'; ${ }^{58}$ noting that '[u]nfair terms pose a threat to this, and firms should consider the implications of having unfair terms in their consumer contracts more widely than as simply breaches of the Regulations'. ${ }^{59}$

Indeed, the United Kingdom's financial services regulator has taken actions in respect of a number of unfair terms within lifetime mortgage products. In 2006, the Financial Services Authority (FSA) published undertakings, which followed a challenge to the terms of a lifetime mortgage contract offered by Scottish Widows plc. ${ }^{60}$ The term under review related to buildings insurance claim monies (payable in the event of fire etc), and provided that in the event of such monies being paid, the lender could determine whether to apply the payment to reinstate the property or to pay off or reduce the debt owed under the mortgage. The FSA noted that a consequence of this term might be that the occupier holding a lifetime mortgage could, in the event of damage to the property rendering it uninhabitable, be left with nowhere to live if the lender opted to pay off or reduce the mortgage rather than reinstating the property. Losing their home could potentially undermine the whole basis of the arrangement from the consumer's perspective, and the FSA indicated its view that this term may have been unfair under reg 5(1) because, contrary to the requirement of good faith, it caused a significant imbalance in the parties' rights and obligations to the detriment of the consumer. Following a challenge by the FSA, the firm agreed to an undertaking to amend the term so that the discretion to apply insurance monies to reinstatement of the property or repayment of monies due under the mortgage was at the consumer's option, and to read the amended term into all its lifetime mortgage customers' agreements.

In another case, the FSA challenged two terms in an equity release contract offered by In Retirement Services (Reversions) Ltd. The first term stated that in the period between the consumer's death and the date that the property was sold, their estate would be responsible for the costs flowing from a series of obligations such as insurance, repairs and taxes, but with no documented obligation on the provider to sell the property within a reasonable time. ${ }^{61}$ While the firm stated that its practice was to sell properties within a reasonable timeframe, the FSA was concerned

$57 \quad$ Financial Conduct Authority, FSA Handbook (19 June 2014) <http://fsahandbook. info/FSA/html/handbook/MCOB>.

58 For details of the Treating Customers Fairly initiative, see Financial Conduct Authority, Treating Customers Fairly (14 June 2014) FSA Handbook <http:// www.fsa.gov.uk/Pages/Doing/Regulated/tcf/index.shtml>.

59 Financial Services Authority, Fairness of terms in consumer contracts: a visible factor in firms treating their customers fairly (2008) [2.14]; see discussion in Fox O'Mahony, above n 4, Chapter 8.

60 Financial Services Authority, Undertaking (September 2006) <http://www.fsa. gov.uk/pubs/other/undertaking_sw.pdf $>$.

61 Financial Services Authority, Undertaking (September 2006) <http://www.fsa. gov.uk/pubs/other/undertaking_irs.pdf>. 
that the term had the potential to go further than was necessary to protect the legitimate interests of the firm. Following the FSA challenge, the firm undertook to introduce a new term which explicitly stated that they will take reasonable steps to sell the property within a reasonable time, with examples of the types of circumstances which might lead to a legitimate delay. $^{62}$

The second term addressed in this challenge gave the firm an absolute discretion in dealing with any management, repair and maintenance of the property which it considered necessary pending sale, with no requirement that the discretion be exercised reasonably, and without reference to the MCOB guidance which states that firms may not be treating their customers fairly if they require consumers to maintain the property to a standard which exceeds the standard it was in when the contract began. ${ }^{63}$ While the firm stated, again, that it did not use the term unfairly in practice, it also undertook to clarify the meaning of the term to reflect the MCOB guidance, as well as adding new wording to explain that any costs beyond those for which the consumer was directly liable would be shared between the parties in proportion to their beneficial interests in the property, and that the share due from the consumer would be paid by deduction from the proceeds of sale when the property was sold. In both cases, these terms were potentially unfair and caused a significant imbalance between the parties to the detriment of the consumer by virtue of the risk that unanticipated costs would accrue against the consumer or his estate. In adjudicating on the terms, the FSA sought to strike a balance between the legitimate interests of the provider in the good repair in light of its claim, in due course, on the capital value, and the consumer's interest in being protected against terms that go beyond what is reasonably needed to protect the firm's legitimate interests.

These examples are illustrative of some of the ways in which the FSA/FCA has exercised governance over the fairness of equity release contracts. There are, of course, significant limitations to this approach to regulation, not least because these individual undertakings bind only the firm that makes them. The undertakings are published, with the advice that 'firms that have not given an undertaking or been subject to a court decision should remain alert to undertakings or court decisions concerning other firms'; yet while these have some potential value in showing the

62 The new term complies with the rules set out in the Mortgages and Home Finance: Conduct of Business Sourcebook (MCOB) r 2.6A.15R, which requires firms to take reasonable steps to sell the property within a reasonable time and for the best price that might reasonably be obtained, but which recognises that 'a balance has to be struck between the need to sell the property as soon as possible, and other factors, such as market conditions, which may prompt the delay of the sale'.

63 Financial Conduct Authority, MCOB 2.6A Protecting customer's interests: regulated mortgage contracts, home purchase plans, home reversion plans and regulated sale and rent back (19 June 2014) FCA Handbook [MCOB 2.6A.11G(1)] <http://fsahandbook.info/FSA/html/handbook/MCOB/2/6A>. 
likely attitude of courts or administrative authorities to similar terms, ${ }^{64}$ their impact in preventing other lapses is limited. In a 2008 review of compliance with the Unfair Terms in Consumer Contracts Regulations, the FSA claimed that, while it 'expects' firms to be proactive in reviewing all their contract terms and other firms' undertakings, firms need to do more to ensure that their terms are drafted fairly ${ }^{65}$ Many of the firms whose contracts had previously been reviewed still had unfair terms in their contracts (in a few cases, the same unfair terms in other regulated contracts) ${ }^{66}$ including one firm which had amended its general contract terms to specifically state that the unfair term applied to all products other than the product the undertaking was provided for' ${ }^{67}$ The issue of 'variation terms' was a particular problem, with over half of the sample of contracts reviewed containing at least one variation term (giving the firm power to impose a change in the contract that the consumer has not explicitly agreed to in advance and that does not require the consumer's agreement when the change is made) that the FSA would deem to be unfair. These findings were described as 'disappointing', leading the FSA to conclude that 'firms need to do more and we encourage them to use the information we provide to help them ensure their contract terms are drafted fairly'. ${ }^{6}$ Progress continues to depend on firms' proactive engagement with the guidance and good practice provided by the FSA.

Within the Australian consumer protection toolkit, the National Consumer Credit Protection Act 2009 (Cth) (NCCPA) introduced a general requirement that all lenders and mortgage brokers 'act responsibly', a requirement which, in the NCCPA context, includes evaluating the suitability (or lack of suitability) of the credit contract in light of the borrower's circumstances (ss 116, 131), making reasonable inquiries about the consumer's requirements and objectives, financial situation, and taking reasonable steps to verify this; with lenders prohibited from suggesting, assisting with or entering into unsuitable credit contracts (ss 123-124, 133). While these provisions signal to the consumer's 'requirements or objectives', and to financial circumstances affecting the ability to meet obligations or comply with terms (including specific reference to assume 'substantial hardship' where financial obligations can only be met by selling the principal place of residence), ${ }^{69}$ they do not refer specifically to the needs of older consumers and - through their focus on the ability to meet financial obligations - are geared towards 'forward' debts rather than 'reverse' debts. As in the United Kingdom, it is not clear that the tools that are available across the general consumer protection landscape are appropriate or adequate to address the particular risks and vulnerabilities likely to arise in a reverse mortgage context.

64 See, eg, preamble to sample undertakings referenced above.

65 Financial Services Authority, above n 58, [3.5].

66 Ibid.

67 Ibid, [3.18].

68 Ibid, [3.46].

69 National Consumer Credit Protection Act 2009 (Cth) s 124(3). 
Indeed, in its 2010 Green Paper, the Australian Government recognised the need for separate provision for reverse mortgages ${ }^{70}$ through industry self-regulation or government regulation, or a combination of the two. Key concerns identified in the Green Paper included the 'information and advice' that reverse mortgage consumers receive - from initial and ongoing disclosure of product and market features to independent legal and/or financial advice; and typical 'terms and conditions' - with Treasury noting that industry norms included the absence of minimum age thresholds, mandatory loan to value ratio, default clauses and procedures, and lack of protection for non-owning occupiers. As the discussion below will demonstrate, while these themes are broadly familiar to the United Kingdom context, the United Kingdom's longer experience in the sector meant that in 2010 the Australian market was still grappling with a set of issues which had been largely addressed in the United Kingdom, either through government regulation (information and advice) or - to some extent - industry practice and self-regulation (some aspects of terms and conditions). Meanwhile, recent research focused on consumer experiences of equity release transactions within the United Kingdom's more established market offers potential comparative insight around these same themes. ${ }^{71}$

\section{B Industry Self-Regulation: the Equity Release Council and SEQUAL}

In the United Kingdom, industry self-regulation pre-dated the FCA's regulation of equity release products, and continues to run alongside the statutory schemes. Members of the Equity Release Council (ERC) provide the majority of equity release products sold in Britain (90 per cent by volume). As a form of self-regulation, it provides a voluntary 'kite-mark' for member equity release providers. All participating companies pledge to observe the Code of Practice, which offers the following guarantees to customers:

1. To allow customers to remain in their property for life, provided the property remains their main residence.

2. To provide customers with fair, simple and complete presentations of their plans. This means that the benefits and limitations of the product together with any obligations on the part of the customer are clearly set out in their literature. It should include all costs that the customer has to bear in setting up the plan as well as the tax implications, their position on moving house and the effects of changes in house values on their loan.

3. The right to move their plan to another suitable property without any financial penalty.

70 Treasury, 'National Credit Reform: Enhancing Confidence and Fairness in Australia's Credit Law' (Green Paper, July 2010). 
4. To give customers the right to an independent solicitor of their own choice to conduct their legal work. The firm must provide the solicitor with full details of the benefits their client will receive before the completion of the plan. The solicitor only signs a certificate once he or she is satisfied that their client fully understands the risks and benefits of the plan.

5. To provide an Equity Release Council certificate, signed by the solicitor, to ensure clients are aware of the terms and implications of the plan, including the impact of equity release on their estate.

6. To give customers a no negative equity guarantee on all equity release plans. This means customers will never owe more than the value of their home and no debt will ever be left to the estate. $^{72}$

This approach is broadly echoed in the SEQUAL approach to self-regulation in Australia, which requires its member-providers to include a 'no negative equity guarantee'; to make clear financial disclosure, including forward modelling; to ensure that consumers receive legal advice; and to submit to an accreditation system governing professional advisors for reverse mortgages. ${ }^{73}$ It is also noteworthy, in the United Kingdom context, that while government regulation now requires that qualifying products protect the customer's right to move house (to a 'suitable property' - the definition of which has raised difficulties in practice), the 'no negative equity guarantee', and the provision for solicitor certification, go beyond the FSA/FCA's rules for lifetime mortgages.

In this respect, the ERC, as an industry self-regulator covering 90 per cent by volume of lifetime mortgage business has intervened in the regulation of terms and conditions to an extent that the government regulator has not. From one perspective, this raises questions about the FSA/ FCA's philosophical and political reluctance to acknowledge and address consumer vulnerability regarding terms and conditions, and the degree to which - as a regulator - it understands what consumers need to give them greater confidence in this market. Alternatively, it could be understood as a feature of a maturing market, in which industry regulation has evolved alongside government intervention, to present a complementary basket of consumer protection.

\section{Targeted Regulation of Equity Decumulation Products and Transactions}

Targeted regulation of reverse mortgages was introduced in the United Kingdom in 2004, under the jurisdiction of the Financial Services Authority (since 2014, the Financial Conduct Authority (FCA)). ${ }^{74}$ The FCA's equity

72 See ERC website, <http://www.equity-release-online.co.uk/content/Equity_ Release_Council.htm>.

73 SEQUAL, Code of Conduct (2014) SEQUAL <http://www.sequal.com.au/ code-of-conduct>.

74 Fox O’Mahony, above n 4, ch 8. 
release regime is primarily geared around the role of information and advice in enabling equity release consumers to make appropriate financial decisions, with specific rules relating to the processes by which the products are advertised, explained and sold to consumers: for example, the regulation of pre-application disclosure ${ }^{75}$ disclosure at the offer stage ${ }^{76}$ and post-sale disclosure. ${ }^{77}$

As in the United Kingdom's conventional mortgage regime, lifetime mortgage regulation and home reversion regulation make use of information disclosure, 'key facts' statements and specific health warnings. A key feature of the United Kingdom's lifetime mortgage regime from its inception was a strong steer towards personalised, professional financial advice, ${ }^{78}$ while home reversion providers were required to receive confirmation from a legal adviser that appropriate advice had been given before proceeding with the sale of a home reversion, ${ }^{79}$ unless satisfied 'on reasonable grounds, based on the customer's knowledge, expertise and experience that it is unnecessary'. ${ }^{80}$ This foregrounding of professional legal and financial advice has been further embedded following the 2012 Mortgage Market Review, with a requirement that all sales ${ }^{81}$ are (financially) advised, with firms required to assess whether the product is appropriate for the consumer. Since the ERC requires that all lifetime mortgage transactions executed by its providers include legal advice (90 per cent of the market), the net effect is that almost all consumers will obtain, paid-for-by-the-consumer, both financial and legal advice.

The Australian regime was set out in the Consumer Credit Legislation Amendment (Enhancement) Act 2012 which, in at least some respects, goes further than its United Kingdom counterpart. For example, in addition to its emphasis on 'information and advice', the 2012 Act creates a statutory 'no negative equity guarantee', as well as regulating other terms relating to default and third party occupants. It has not yet required that consumers receive mandatory, independent, financial and/or legal advice, although it has been suggested that this may be an area for future reform. ${ }^{82}$ The United Kingdom experience has indicated that this is likely

75 Financial Conduct Authority, FSA Handbook - MCOB 5 (19 June 2014) <https:// www.handbook.fca.org.uk/handbook/mcob/>.

76 Financial Conduct Authority, FSA Handbook - MCOB 6 (19 June 2014) <https:// www.handbook.fca.org.uk/handbook/mcob/>.

77 Financial Conduct Authority, FSA Handbook - MCOB 7 (19 June 2014) <https:// www.handbook.fca.org.uk/handbook/mcob/>.

78 In contrast to the conventional mortgage regime, the required statement for lifetime mortgages did not identify the main risks of the product, but directed consumers towards obtaining individual advice, with the health warning that ' $[\mathrm{t}]$ his is a lifetime mortgage. To understand the features and risks, ask for a personalised illustration': Financial Conduct Authority, FSA Handbook - MCOB 3.6.13 (19 June 2014) <http://fsahandbook.info/FSA/html/handbook/MCOB/3/6>.

79 Financial Conduct Authority, FSA Handbook - MCOB 2.6A.5 (19 June 2014) $<$ http://fsahandbook.info/FSA/html/handbook/MCOB/2/6A>.

80 Ibid.

81 Excluding sales to 'high net worth individuals' or mortgage professionals.

82 Burns, above n 7, 650; citing ASIC, above n 6, Recommendation 8. 
to raise some important issues relating back to the nature of the consumer population. The emergence of the United Kingdom's 'advice paradigm' in cases of higher-risk is effectively an extension of the more broadly embedded 'information paradigm'. ${ }^{83}$ Yet, as the post-financial crisis era of financial services regulation has brought the adequacy of consumer protection strategies rooted in providing information (and arguably, by extension, advice) to enable informed consumers to make rational choices under renewed scepticism, ${ }^{84}$ and under the shadow of Wilhelmsson's claim that 'measures based on the information paradigm [as liable to] reproduce and even strengthen existing social injustice'; 85 the importance of appropriately aligning regulation to the needs of consumers and the evolution of the market is brought into sharp relief.

In a recent empirical research project with United Kingdom consumers, we explored the extent to which mandatory advice delivers effective consumer protection for consumers across a range of socio-economic contexts. ${ }^{86}$ Our findings identified important differences in the extent to which financial advice is useful in helping older people to negotiate the equity release market, and to be clear about the implications of their decisions. While financial advice was viewed as worthwhile and helpful by many consumers, it was most useful for those (predominately betteroff consumers) who were prepared to receive advice, who had already researched the options and who knew what questions to ask. Furthermore, the research found that equity release decisions were informed by a range of psychological biases and contextual factors including personal and financial circumstances, embeddedness within particular communities and networks, and the nature of the relationship between consumer and financial adviser. This implied that the information and advice paradigms (upon which the regulatory framework is based) are of limited and unequal value in delivering consumer protection: calibrated to the needs of less vulnerable consumers (those who are able to research, plan, and know what questions to ask, either because they are financially capable

83 While the provision of information typically involves explaining processes or making people aware of options, advice involves helping the client to evaluate options and recommending which course of action is best in their particular situation. Yet, the distinction between information and advice is not straight-forward, and the FSA's Mortgage Effectiveness Review found that equity release consumers were unlikely to perceive a distinction between information and advice.

84 Disclosure regulation has long been criticised as based on an: '[U]nrealistic, rational actor model of borrower behaviour'; Lauren Willis, 'Decision making and the limits of disclosure: The problem of predatory lending: Price' (2006) 65 Maryland Law Review 707, 741; as a 'protection for the middle classes'; George Day, 'Assessing the effects of information disclosure requirements' (1976) 40 Journal of Marketing 42, 49; Geraint Howells, 'The potential and limits of consumer empowerment by information' (2005) 32 Journal of Law and Society $349,357$.

85 Thomas Wilhelmsson, 'Consumer law and social justice' in I Ramsey (ed), Consumer law in the global economy (Aldershot: Dartmouth, 1997) 224.

86 Fox O'Mahony and Overton, above n 39. 
themselves and/or have friends or family who can help them to prepare), it is least effective in protecting the most vulnerable consumers.

While the ongoing Australian regulation debate will necessarily be contextualised by the evolving Australian market, it should also, critically, be shaped by research into the specific needs of the Australian consumer population. Our recent United Kingdom research has highlighted the importance of penetrating the complex configurations of market offer, consumer population and state intervention in any given jurisdiction when evaluating the appropriateness of particular approaches to financial services regulation in this sector. As political expectations on the role of housing equity in meeting later life needs grow more demanding and complex, and the economic environment, including historic long-term low gilt and annuity rates, leaves older people reaching retirement will less financial scope to stretch their pensions and therefore more pressure on their accumulated asset-base to cover a range of needs and wants, the industry's growth strategy and law's regulatory approach must be based on a clear and robust understanding of the potential equity release consumer population's needs, objectives and circumstances in retirement. As older owners negotiate the complexities of sustaining health, wealth and hearth in an Ageing Australia, it is crucial that the financial products and services available to older owners are attractive and appealing to them; and that both the products themselves and transactional protections positioned around reverse mortgage transactions are adequate to meet the needs of a broad potential equity release population. As the new Australian provisions bed in, independent consumer research to evaluate the effectiveness of the new approach to regulation - sensitive to the needs, objectives and circumstances of more and less well-off owners, those who live in urban and rural areas, older old and younger old, and so on - will be important to enable the State to understand how best to temper the balance between the reverse mortgage market and a diverse population of older owner consumers, and so to create the environment in which this strategically significant sector can optimally serve the needs of consumers, the industry and policymakers.

\section{Conclusions}

In her detailed analysis of the evolution of reverse mortgage regulation in Australia, Burns suggested that the family home has 'only been recently "discovered" as an additional source of retirement income, so that government policy towards the family home and equity release is still developing and dependent upon how the ageing of the population affects economic growth and government finances'. ${ }^{87}$ In a policy context geared towards the liquidation and use of accumulated housing assets to meet needs in later life, the nature and extent of appropriate consumer protection for financial transactions that release housing equity must be determined in the context of the evolving market (from product design to industry regu- 
lation) and sensitive to the needs of the consumer population, particularly the most vulnerable consumers. With this in mind, the more established United Kingdom market offers a useful comparator for the evolving Australian market. Equity release products are a form of 'credence good': their suitability and pricing depends on unknowable future events (future house value, longevity of the owner, future health and mobility needs, future financial needs), so the utility impact of the product is difficult to ascertain before consumption. Consumers may feel very differently about the level of debt that is owed several years later, and they may have become more aware of features of the product which enhance or detract from its suitability for their needs, objectives and circumstances. The United Kingdom's longer track record in the market, alongside a growing body of consumer research, offers useful perspectives on the nature of the relationships between the market, consumers, and the State, in this sector of the financial services market. With this strategically significant sector of the Australian financial services market poised to play an important role in the ageing society, it will be crucial to develop evidence-based understandings of the meaning of appropriate and effective consumer protection in reverse mortgage transactions, calibrated to the composition, needs, and experiences of the Australian consumer population. 